free from nicotin Efforts were being made to produce a grape whioh was resistant to Phylloxera and Peromospora, by extensive crossing with North American varieties and subsequent selection. Baur visited Peru and Bolivia, bringing back many native varieties of potato for use in plant breeding. Other large-scale crosses were made for the improvement of gooseberries, raspberries, blackberries and tomatoes.

In 1908, Baur founded and edited the Zeitschrift fuir induktive Abstammungs- und Vererbungslehre, which has remained one of the standard journals for genetical researches and publishes a comprehensive classified bibliography of the world literature. $\mathrm{He}$ also founded the Bibliotheca Genetica, Der Züchter, and was joint editor of the Zeitschrift für Pflanzenzüchtung Gartenbauwissenschaft and Berichte über die gesamte wissenschaftiche Biologie. With Dr. M. Hartmann he had produced since 1928 the "Handbuch für Vererbungswissenschaft". He was thus instrumental in giving publication to a very large amount of important genetical work. Baur, with Fischer and Lenz, wrote the well-known "Menschliche Erblichkeitslehre und Rassenhygiene", which has seen several editions. At the fifth International Congress of Genetics, held at Berlin in 1927, he was a leading spirit and gave the opening address as president of the local committee.

Prof. Baur was an honorary member of many scientific societies and was elected a foreign member of the Linnean Society of London in 1933. An indefatigable worker, his results have been among the most fruitful in modern plant genetics.

R. Ruggles Gates.

\section{Prof. W. E. GibBs}

IT is with great regret that we record the death on January 18 of Prof. William Edward Gibbs, at the early age of forty-four years. Prof. Gibbs was the Ramsay professor of chemical engineering at University College, London, having been appointed to that post on the resignation in 1928 of Prof. E. C. Williams. At the time of his appointment a large extension of the Department of Chemical Engineering had been planned, as the result of generous donations from various important British chemical firms, obtained through the energetic propaganda of his predecessor. The extension was designed and carried out by Prof. Gibbs with conspicuous ability and success, and within a few years his genial personality, combined with his deep interest in research, his organising power and his practical knowledge of industrial methods and processes, had filled the much enlarged laboratory with a band of enthusiastic students drawn from many sources-young British university graduates, experienced men from various industries, and foreign students.

Prof. Gibbs was a graduate of the University of Liverpool, and obtained his first post as assistant chemist to the Straits Trading Company at
Singapore. Having held this post for a few years he returned to the University of Liverpool, and the present writer recollects the enthusiasm with which he attacked the problem of the electrochemical recovery of metallic tin from the waste smelter material which he had brought home with him. At Liverpool he was soon appointed lecturer in metallurgy, and he was also made investigator to the Corrosion Committee of the Institute of Metals.

During the War, Prof. Gibbs rendered valuable service to the country, holding successively the posts of chief examiner of the Aeronautical Inspection Department, and chief chemist to the Government Rolling Mills at Southampton. At the conclusion of the War he was appointed chief chemist to the Salt Union, a post which he held until appointed professor at University College. During this period he acquired an extensive practical acquaintance with the technical methods and problems relating to evaporation and crystal. lisation.

Prof. Gibbs was deeply interested in the properties and treatment of aerosols and aerogels, that is, disperse systems in gases, and wrote two excellent books, "Clouds and Smokes", and "The Dust Hazard in Industry", which are, so far as the present writer is aware, the first scientific expositions of these important subjects in book form in the English language. He was also very much interested in problems relating to heat exchange, the flow of liquids and gases, the fractional distillation of liquid mixtures and the design of gas-scrubbers and rectifying columns. In these and other fields of chemical engineering he understood well how to combine the theoretical basis of design with the practical aspects of construction and operation, and he possessed the supreme gift of awakening and sustaining the intelligent interest of his students and securing their loyal and indeed affectionate co-operation.

Prof. Gibbs was a man of high, unselfish and sterling character, combined with an endearing charm and simplicity of personality not often encountered in this world. His untimely death is a severe loss, not only to his colleagues and students at University College, but also to the Institution of Chemical Engineers and the science and practice of chemical engineering throughout the world.

F. G. D.

\section{Dr. Hermann Christ-Socin}

BARELY three weeks before his hundredth birthday, and still fully in possession of his physical and mental faculties, Dr. Hermann Christ, the Nestor of European botanists, had the misfortune to slip on the polished floor of his stady and to fracture his leg. Unfortunately, too, complications set in and he died on November 24 at his home in Riehen near Basle.

Though known throughout the world as a botanist, Dr. Christ was by profession a lawyer, for which career he prepared himself by studies in the Universities of Basle and Berlin. But, interested 